\title{
A novel view of a warming world
}

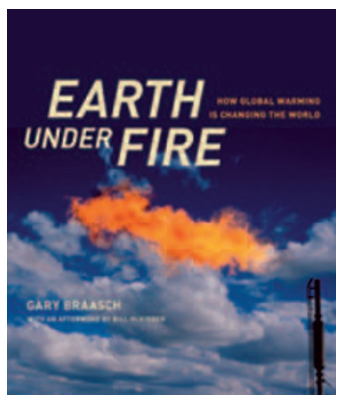

\section{EARTH UNDER FIRE: HOW GLOBAL WARMING IS CHANGING THE WORLD}

\author{
by Gary Braasch \\ University of California Press: 2008. 295pp. \$34.95/£19.95 \\ In the growing clamour over global warming, eye-witness \\ accounts of a changing world stand out.
}

Amidst the current rash of paperback polemics on climate change, finding a refreshing viewpoint can be a tough challenge. Starting from his personal photographic collection documenting the impacts of a warming world, photojournalist Gary Braasch rises to that challenge in Earth under Fire. But unlike classic photographic records of environmental change, such as The Changing Mile by Hastings and Turner (1965), which records vegetation change in Arizona between the 1890s and 1960s, or Le Roy Laurie's Times of Feast, Times of Famine (1967), which documents one of the earliest photo sequences of glacier retreat, Earth under Fire goes beyond presenting a pictorial record of change.

Braasch, a contributor to National Geographic, merges his personal photographic journey to some 45 sites around the world with in-the-field reporting of the changes taking place, the scientists carrying out the research and the stories from those already being affected, such as the Inuit of the Arctic, to lend context and meaning to the imagery.

Designed to bring the reader into the hearts and minds of those observing climate change, this approach is supported by weighty scientific evidence that lends further credibility to the stories. Throughout, the text is replete with references to recent climate research, and the narrative is supplemented with expert summaries from some of the top names in climate science on topics such as the retreat of Arctic ice, the spread of human disease and the loss of biodiversity.

In documenting the retreat of mountain glaciers, for example, Braasch provides more than before-and-after sequences of the extent of glaciers today as compared with 30 years ago. He cites research showing that in China's

western provinces and in Tibet, glaciers have lost 7 to 27 percent of their mass over the past 60 years. And he follows the work of glaciologist Lonnie Thompson, who in the past 30 years has assembled a story of longterm climate patterns from glaciers all over the world. Braasch describes Thompson's work from the field to powerfully convey the message of those observing change first-hand:

\begin{abstract}
The accelerating melting worldwide is driving Thompson to return to some of his previous study glaciers to precisely measure their diminishment. At Quelcccaya [in the Andes] in July 2004 he found preserved clumps of Distichia muscoides moss melting out from the sole of the glacier; radiocarbon dating placed them at 3000 B.C. He is mindful of the difficulty of proving these dates beyond doubt. "So many things in science you can question. But when you find wetland plants... perfectly preserved; they had to be buried and stay under the ice until now. It's a powerful message" he said. "It has not been warmer there for 5,000 years".
\end{abstract}

Added to eye-witness accounts of change in the Arctic are stories Braasch has collected from local Inuit - of slumping settlements due to permafrost melt, eroding coasts and warmer seas - that build a convincing and disturbing portrait of change. Of course, the environmental record is often messy and the take-home message of research itself is not always clear. Braasch does not work through differing lines of evidence in a balanced way, and experts would criticize him for picking what suits him.

Perhaps Braasch should have played only his strong suit: documenting the effects of a warming world. But he takes the plunge into addressing the question of how to meet this challenge, and his risk is rewarded. What normally would be a dull repetition of emissions reduction policies becomes, in this author's hands, a refreshing take on theories, facts and scientific opinions, sprinkled with comment from leading policymakers. Braasch has told the story of climate change in a new way by bringing together startling and breathtaking imagery with personal accounts and the best available scientific evidence.

Having changed my mind three times about this unusual book, I finally decided it is rather special. I first expected it to provide a longitudinal photographic record of how this world is changing - according to its subtitle, How Global Warming is Changing the World. Once I started reading instead of glancing, it appeared to be a much less interesting work on one photojournalist's personal view of climate change. But ultimately, and much more satisfyingly, it turned out to be a well-illustrated and very up-to-date guide to how scientists are going about their work uncovering the story of global warming.

Though this glossy, large and heavy hardback could grace any coffee table and is the perfect book to inform the interested layman, it would equally be of interest to scientists, with its first-hand accounts from researchers in the field and Braasch's engaging narrative conveying their excitement in discovery.

\section{Published online: 21 February 2008.}

\section{doi:10.1038/climate.2008.16}

\section{Martin Parry}

Martin Parry is co-chair of Working Group II (Impacts, Adaptation and Vulnerability) of the Intergovernmental Panel on Climate Change and is in the Centre for Environmental Policy at Imperial College London. e-mail:parryml@aol.com 